\title{
DOVEDNOST PERCEPCE A DEKÓDOVÁNÍ PSANÉHO TEXTU (NEJEN) U STUDENTŮ NEFILOLOGICKÝCH OBORŮ
}

\author{
Martin Lachout \\ Metropolitní univerzita Praha, Katedra cizích jazyků, \\ Dubečská 900/10, 10031 Praha 10, Česká republika \\ e-mail: martin.lachout@mup.cz \\ Univerzita Jana Evangelisty Purkyně, Filozofická fakulta, Katedra germanistiky, \\ Pasteurova 3544/1, 40096 Ústí nad Labem, Česká republika \\ e-mail: martin.lachout@ujep.cz
}

\begin{abstract}
Příspěvek je věnován receptivní dovednosti čtení s porozuměním. Po teoretickém úvodu v něm autor představuje pilotní studii, která byla realizována u vybraných českých vysokoškolských studentů nefilologicky zaměřených studijních oborů. Cílem studie bylo zjistit, jakým způsobem respondenti pracují s odborně zaměřeným textem, jakých strategií využívají a zda jsou schopni takovýto text úspěšně dekódovat.

Na základě získaných dat vznikl návrh klíčových kompetencí dle ERRJ reformulovaných s ohledem na čtení s porozuměním odborně zaměřeného textu.
\end{abstract}

\section{Keywords}

Reading competence; Top-down process; Bottom-up process; Reading strategies; Pilot research; Descriptors.

\section{Úvod}

Dovednost čtení patří k jedné z klíčových dovedností každého uživatele jazyka. Její význam je tím více umocněn u těch uživatelů, kteři se pohybují v odborně orientovaném pracovním prostředí nebo se na svou odbornou profesní dráhu teprve připravují. Právě oni jsou/budou nuceni pracovat s cizojazyčnými odbornými texty a tyto obsahově správně dešifrovat, aby byli bud’to schopni aplikovat nově získané poznatky do své odborné práce, nebo o problematice fundovaně diskutovat na odborné úrovni s kolegy. $\mathrm{Na}$ tomto místě souhlasíme se Schröderem [1], který je toho názoru, že rozvoj dovednosti čtení a práce s textem představuje pro mnoho učících se nejdůležitější cíl cizojazyčné výuky s ohledem na jejich budoucí odborné profesní zaměření. Právě této dovednosti byl věnován níže prezentovaný výzkum, který byl realizován u českých studujících nefilologicky zaměřených studijních oborů na Metropolitní univerzitě v Praze (MUP) a paralelně u studujících technicky zaměřených studijních oborů na Technické univerzitě v Košicích. Tento př́spěvek však popisuje pouze výsledky získané od studentů MUP.

Podobným výzkumům se v minulosti u nás věnoval např́iklad Ottokar Veselý [2], ze zahraničních autorů pak kupř. Uta Weis [3] nebo Hyun-Sook Jung [4].

\section{Proces percepce a dekódování psaného textu}

K percepci a dekódování psaného textu dochází v rámci jedné ze čtyř řečových dovedností, a to při dovednosti čtení (s porozuměním). Podle Pedagogického slovníku [5] představuje čtení 
„druh řečové činnosti spočívající ve vizuálni recepci znaki̊ (slov, vět, nejazykových symbolů), jež jsou podnětem pro myšlenkovou činnost (porozumění významu znaků). Proces čtení zahrnuje několik fází, jejichž výsledkem má být ideálně porozumèní čtenému textu (angl. reading comprehension) a vnitřní zpracováni př́slušné informace“.

Čtení tak představuje komplexní činnost, která variuje v závislosti na charakteru textu, na předem stanovených cílech, na stylu práce s textem a mnoha dalších proměnných.

„Pochopení slova, slovních spojení, či celého textu v cizím jazyce přináši s sebou celou řadu potiží, které nenastávají při čtení v rodném jazyce“ [6].

V rámci procesu čtení se totiž jedná nejen o jazykové, ale i o kognitivní zpracování psaného textu, které probíhá dvěma způsoby:

1. Na jedné straně dekódujeme $\mathrm{v}$ textu kódovanou informaci prostřednictvím našich dříve nabytých znalostí a všeobecných zkušeností a na základě našich předchozích zkušeností čtenářských. Přitom aktivujeme takové procesy, které vycházejí z psaného textu, jde tedy o procesy, které jsou založeny na již existujících datech (informacích jazykového lexikálně-gramatického charakteru, bazírující na probabilní struktuře vět) a které z psycholingvistického hlediska probíhají tzv. bottom-up (zdola nahoru). Jinými slovy se tedy jedná o predikci jazykovou.

2. Na straně druhé jsme pak schopni pomocí našich předchozích znalostí interpretovat $\mathrm{v}$ textu kódovaný obsah. $\mathrm{V}$ tomto případě aktivujeme ty procesy, které vycházejí z našeho chápání, jsou tedy řízeny našimi očekáváními a probíhají oproti prvně uvedeným tzv. topdown, tedy shora směrem dolů. $\mathrm{V}$ tomto př́padě jde o predikci obsahovou.

U obou uvedených procesů však hraje velmi významnou roli kontext. Proces čtení prochází různými úrovněmi zpracování jazykové i kognitivní informace. Tyto úrovně v sobě zahrnují mj. rovinu grafických znaků (grafémů), rovinu slov, jejich morfologie a syntaxe, jakož i jejich sémantiky. Takové procesy pak kladou zvýšené nároky na náš kognitivní systém, které jsou při vědomé kontrole vysoké, při zautomatizovaných procesech naopak nízké. Výsledkem tohoto procesu zpracování pak je pochopení kódovaného sdělení.

Čtení přitom nelze chápat jako pouhý pasivní př́jem obsahu sdělení, nýbrž i jako aktivní vypořádání se čtenářre $\mathrm{s}$ textem, které vede $\mathrm{k}$ rekonstrukci významu kódovaného ve sdělení. Výsledek této rekonstrukce se však může zásadně lišit od původně zamýšlené interpretace autora nebo od interpretace ostatních čtenářů. To je patrné např́íklad při četbě uměleckých nebo filozofických textů, více či méně jednoznačná interpretace je např́klad u textu na jízdence vlaku nebo na jízdním řádu, relativně jednoznačná je i u odborných textů. Míra těchto odchylek v dekódování je tedy závislá na charakteru textu.

Ve značně zjednodušeném podání se psaný text skládá z prvků, které jsou hierarchicky uspořádány. Písmena vytvářejí slova, slova vytvářejí věty, věty nadvětné celky, tyto celky pak celkový text.

Procesy, s jejichž pomocí je psaný text čtenářem zpracováván, těmito rovinami procházejí a vzájemně je mezi sebou propojují.

Při analýze čteného textu přitom rozlišujeme mj. následující úrovně:

- Grafo-fonematické dekódování grafických znaků: Při rutinním čtení čtenář vnímá text rychlými pohyby očí (tzv. sakádami), po nichž následující fixace určitých bodů po dobu trvání milisekund. Přitom standardně nejsou fixována celá slova, nýbrž jen jejich části (zpravidla jejich první slabiky), a zdaleka přitom nejsou fixovány části každého slova. 
Lidský mozek totiž dokáže i na základě fixace fragmentu lexému rozpoznat zbytek daného slova. $\mathrm{V}$ tomto př́padě se jedná o jakousi schopnost asimilativního doplňování slov, při němž čtenář uplatňuje své vlastní znalosti jazyka a probability výskytu jemu známých syntaktických struktur jazyka. Při čtení jsme schopni vnímat asi 3 až 4 grafémy nalevo od fixačního bodu asi kolem 10 písmen napravo od tohoto bodu. Následně se přesouváme od jednoho fixačního bodu $\mathrm{k}$ dalšímu. Čím obtížnější je text, tím vyšší je frekvence a délka sakád i fixačních bodů. U cizojazyčných textů nebo u nezkušených čtenářů dochází z důvodu absentujícího zautomatizování nezř́ídka $\mathrm{k}$ fixaci celých slov. Naopak o co zkušenější čtenář je, o to kratší je u něho doba fixací, sporadicky nebo vůbec u něho nedochází k regresivním pohybům očí a o to větší rozsah zabírá jeho čtecí pole, které vnímá $\mathrm{v}$ rámci jedné fixace. Inhibičním faktorem $\mathrm{v}$ procesu tichého čtení je naopak aktivace zvukové podoby slov, a to v podobě tzv. vnitřní řeči (srov. [7]), která zpomaluje čtenářovy kognitivní procesy. K této aktivaci dochází opět nejčastěji u nezkušených čtenářů nebo u čtenářů $\mathrm{s}$ nedostatečnou jazykovou kompetencí. U zkušených čtenářù se tato skrytá artikulace bud'to nevyskytuje vůbec, nebo jen velmi zrrídka.

- Dekódování slov na lexikální rovině: Každý recipovaný tvar slova je konfrontován s již v našem mentálním lexikonu uloženými záznamy, lemmaty. Tento proces probíhá tak, že je lexém, který má být dekódován, porovnáván s jednotlivými zápisy po jednotlivých hláskách. Ty lexémy, které se formálně ani morfologicky nekryjí, jsou z repertoáru možných kandidátů vyřazeny a tato selekce probíhá tak dlouho, dokud nezůstane vyfiltrován jediný vhodný kandidát. Tomu, je-li to možné, je pak v závislosti na tvaru prriřazen patřičný význam, jedná se o tzv. teorii kohort, srov. [8]. Celý proces probíhá s neuvěřitelnou rychlostí, kterou si nejsme jako čtenáři vůbec schopni uvědomit. Přitom jsou zde brány v úvahu také další významy, které vyplynuly z již přečteného, jakož i užší či širší kontext, stejně tak jako gramatická struktura věty. Předpokladem pro úspěšné dekódování významů slov je rovněž tzv. koherence, tedy vnitřní, sémantický vztah mezi jednotkami textu.

- Sémantická rovina komplexního zpracování významu: Informace, které byly dekódovány v jednotlivých úsecích textu, jsou v této fázi integrovány do vlastního vědomí čtenáře. Důležitou roli zde hrají předchozí znalosti a vědomosti recipienta, které se demonstrují ve formě kognitivních schémat. Jedná se např́íklad o bližší vědomosti a znalosti daného tématu nebo celkové znalosti a vědomosti čtenáře. Uvedených kognitivních schémat čtenář využívá $\mathrm{k}$ tomu, aby byl schopen dekódovat $\mathrm{v}$ textu mnohdy implicitně uvedené informace (jde o tzv. inference).

Procesy čtení probíhají těmito úrovněmi interaktivně ve vzestupném a sestupném směru.

Při čtení hrají roli rovněž dlouhodobá a krátkodobá (operativní) pamět', které se vzájemně doplňují. Dlouhodobá pamět' poskytuje v podobě jazykových znalostí, předchozích znalostí práce $\mathrm{s}$ textem a celkových znalostí chápání světa takové kognitivní prostředky, s jejichž pomocí je možné text dekódovat a zároveň s tím mu přiřadit i význam. Vlastní zpracování textu se však odehrává v paměti operativní. Ta je ve svém rozsahu značně omezená, nebot' je schopna zpracovat u průměrného jedince $7 \pm 2$, tzv. Millerovo číslo - srov. [8], kognitivních jednotek, engl. tzv. chunks (smysluplné jednotky). Tyto chunky mohou být jednotky jazykové, mohou jimi být ale i celé subprocesy zpracování. Čím rozsáhlejšsí a komplexnější jsou tyto chunky, které pracovní pamět' vnímá jako jeden celek, tím rychleji a efektivněji může probíhat zpracování celého textu.

Z uvedeného tedy vyplývá, že výhodou jsou při procesu čtení zautomatizované procesy dekódování textu. Operativní pamět' pak tyto procesy vnímá de facto jeden jediný chunk, čímž nevyčerpává svou celkovou kapacitu. Rozpoznává-li tedy trénovaný čtenář rovnou celé 
slovní tvary, aniž by musel dekódovat jednotlivé hlásky, a je-li zároveň schopen přiřadit rozpoznanému tvaru odpovídající význam, pak nejenže dokáže číst výrazně rychleji než čtenář netrénovaný, nýbrž dokáže při přiměřené rychlosti čtení významně ulevit i své operativní paměti, která se tak bude moci více soustředit na zpracování obsahových úloh na vyšších textových úrovních. Přitom nejde o to, že by trénovaný čtenář snad vždy musel číst rychleji než netrénovaný, jde o to, že čte detailněji a s vyšší výtěžností. Operativní pamět' netrénovaného čtenáře je naopak natolik vytížena procesem dekódování a analýzou jednotlivých slov, že jí již nezbývá kapacita pro analýzu textu ve vyšších rovinách, zjednodušeně řečeno, čtenář zůstává uvězněný v rovině lexikální a velmi obtížně chápe smysl celého textu.

Pro efektivnější dekódování textu je proto vhodné osvojení si jednotlivých strategií práce s textem a tyto kvalitně automatizovat. S ohledem na rozsah stanovený pro tento článek se zde nebudeme zabývat jednotlivými typy čtení (orientační, selektivní, kurzorické a úplné, blíže $\mathrm{k}$ této problematice Lutjeharmsová [9] nebo tzv. skimming, scanning, reading for gist - Wolff [10], nýbrž přejdeme rovnou k čtenářským strategiím, které byly předmětem našeho pilotního výzkumu.

\section{Strategie používané při čtení}

Čtenářské strategie jsou takové postupy, které čtenáři pomáhají k tomu, aby lépe porozuměl čtenému textu. Jedná se o jeho záměrné a cílené pokusy kontrolovat své schopnosti dekódovat text a porozumět jeho obsahu. Tyto strategie tak souvisí se záměrným kontrolováním vlastního porozumění. Čtenářské strategie čtenář záměrně používá zejména tehdy, setká-li se s pro něj náročnějším textem.

Jak vyplývá z výsledků stanovených v rámci kognitivně-psychologických výzkumů, je průběh zpracování jazyka řízen mj. pomocí jistých strategií, které jsou označovány jako strategie zpracování jazyka, srov. např. [11]. Vedle nich ovšem existují i tzv. učební strategie, které však nacházejí své uplatnění také při práci s jazykem (textem). Bimmel a Rampillonová [12] tyto strategie definují následovně:

„Eine Lernstrategie ist ein Plan, den jemand im Kopf hat, um ein Ziel zu erreichen. Fremdsprachenlernende wenden sie an, um eine Fremdsprache möglichst erfolgreich zu lernen: Lernstrategie ist ein Plan (mentalen) Handelns, um ein Lernziel zu erreichen ".

Bimmel a Rampillonová ve své publikaci [12] dále uvádějí řadu učebních strategií, my z nich však záměrně vybíráme pouze ty, které mají vztah k procesu čtení a dekódování psaného textu. $\mathrm{S}$ naším tématem souvisí rovněž problematika primárnosti ústní kompetence a její kooperace $\mathrm{s}$ odbornou čtenářskou dovedností. O ní detailně pojednává ve svém článku Bohušová [13]. Tatáž autorka se dále věnuje i problematice vztahu průnikových jevů textu s hybridností aktuálních komunikátů [13] a [14]. Těmto tématům však zde nemůžeme věnovat pozornost, zainteresovaní čtenáři se však $\mathrm{s}$ nimi mohou blíže seznámit v uvedených publikacích.

Osvojení si strategií aplikovatelných při čtení představuje, podobně jako je tomu i u ostatních strategií, jakýsi nadstavbový cíl vyučování cizím jazykům. Naši studující by si tedy měli být dobře vědomi toho, že př̀ čtení cizojazyčného textu nejde o to, porozumět každému jednotlivému slovu, nýbrž o to, aby byli pro dekódování a pochopení textu schopni využít svých předchozích znalostí, zkušeností a právě oněch osvojených strategií. Mnoho nezkušených čtenářů se totiž v cizím jazyce snaží textu porozumět tzv. slovo od slova, přitom je ale neznalost množství slov, která nemají uložena ve svém mentálním lexikonu, často demotivuje a od čtení odrazuje. V př́padě strategického čtení jde o to oprostit se od snahy 
o dekódování významu jednotlivých lexémů, mělo by jít spíše o snahu zaměřit se na dekódování celkového kontextu. V odborné literatuře (mj. napr. [15]) pak tuto schopnost a nezbytné předchozí znalosti označujeme jako ony čtenářské strategie.

Bimmel [15] shrnuje tyto strategie následovně do tří skupin, které navíc doplňujeme:

1. Strategie na úrovni textu.

2. Strategie na úrovni věty.

3. Strategie na úrovni lexikálních jednotek.

Ad 1. U strategií na úrovni textu se jedná o následující:

- aktivace předchozích znalostí a zkušeností ve vztahu k obsahu textu,

- vytvoření si očekávání čtenáře (schopnost vytvářet hypotézy k obsahu textu),

- vytvoření si čtenářského záměru,

- verifikace př́ípadně revize svých očekávání k textu,

- dekódování základních informací obsažených v textu (podtrhávání čísel, jmen, pasáží v textu, analýza grafů a tabulek ap.),

- vytváření si poznámek ke klíčovým myšlenkám nebo informacím v textu,

- rozklíčování výstavby textu na základě jeho makrostruktury atd.

Ad 2. V príípadě strategií na úrovni věty můžeme jmenovat následující:

- podtrhávání klíčových slov,

- podtrhávání textových konektorů a uvědomování si vztahů, které signalizují,

- schopnost predikovat, jaké informace mohou po daných konektorech následovat,

- znalost základních syntaktických struktur,

- vytvářet kontextové vztahy (reference), tzn. prvky věty, které znovu tematizují nebo podtrhují informace, které již byly v textu zmíněny, např̀. osobní nebo přivlastňovací zájmena, zájmenná př́islovce ap.

Ad 3. Na úrovni lexikálních jednotek jde o:

- využívání tzv. cognates (jimi rozumíme slova v cizím jazyce, která se podobají slovům v L1, popř. L2) a internacionalismy,

- znalost základních pravidel slovotvorby (pro němčinu kompozice, derivace, zkracování), které mohou pomoci prri dekódování významu slov,

- využívání kontextu (svou roli zde hrají i jednotlivé konektory).

\section{$3 \quad$ Pilotní výzkum u studujících nefilologicky zaměřených oborů}

Abychom výše uvedené teoretické poznatky aplikovali do praxe a zároveň je i ověřili, zrealizovali jsme mezi našimi studenty nefilology původní pilotní výzkum.

Konkrétně se jednalo o 65 studujících Metropolitní univerzity Praha, studijních oborů mezinárodní vztahy, veřejná správa, humanitní studia a mezinárodní obchod. Všichni respondenti studovali německý jazyk jako druhý cizí jazyk a dosahovali úrovně B1 (38 studujících), resp. B2 (27 studujících) dle SERR. Pro náš účel jsme zvolili kombinovaný kvalitativně-kvantitativní výzkum, v jehož rámci jsme aplikovali dvě výzkumné metody, explorativní metodu dotazníku a metodu didaktického testu.

Studujícím jsme nejprve předložili sebeevaluační dotazník, na jehož základě jsme chtěli zjistit, jakým způsobem respondenti s textem pracují a jakých čtenářských strategií at' už vědomě, či nevědomě používají.

Na základě získaných dat jsme zjistili, že: 
- Jen $65 \%$ respondentů bylo v rámci svého sekundárního vzdělávání konfrontováno s prací s textem.

- $94 \%$, dotázaných pracovalo pouze s učebnicovými texty, $6 \% \mathrm{~s}$ texty originálními.

- $78 \%$ respondenti̊ pracovalo s texty hlavně ve formě doplňovacích cvičení, u $<22 \%$ byla zastoupena cvičení substituční, jen výjimečně byla uváděna cvičení rekonstrukční.

- $52 \%$ respondentů používá při práci s neznámým textem překladový slovník, $37 \%$ odhaduje neznámá slova na základě kontextu, $48 \%$ si podtrhává klíčová slova, $22 \%$ si barevně zvýrazňuje pasáže textu, 7 \% používá výkladový slovník (viz ukázka grafu na obrázku č. 1 - Fig. 1).

- $50 \%$ procent studujících uvedlo, že čte mimo výuku německy psané noviny a časopisy, $37 \%$ čte odborné texty a $23 \%$ beletrii.

- Studenti používají při čtení odborného textu ve $46 \%$ selektivních strategií (zaměřují se dle potřeb na hledání konkrétní informace), v $31 \%$ globálních strategií (zaměřují se na vyhledání hlavní informace), $35 \%$ totálních (úplnou) strategií.

- Na otázku, co je pro studující při čtení odborného textu obtížné nebo limitující, uvedli:

$\checkmark$ nedostatečná slovní zásoba,

$\checkmark$ sémantika termínů a cizích slov,

$\checkmark$ při koncentraci na celkový obsah nejsou schopni sledovat kontext, ztrácejí tak smysl celého textu,

$\checkmark$ dlouhá kompozita $v$ němčině a jejich dekódování,

$\checkmark$ komplikované syntaktické struktury,

$\checkmark$ nominalizace.

\section{Jakým způsobem pracujete s neznámým textem?}

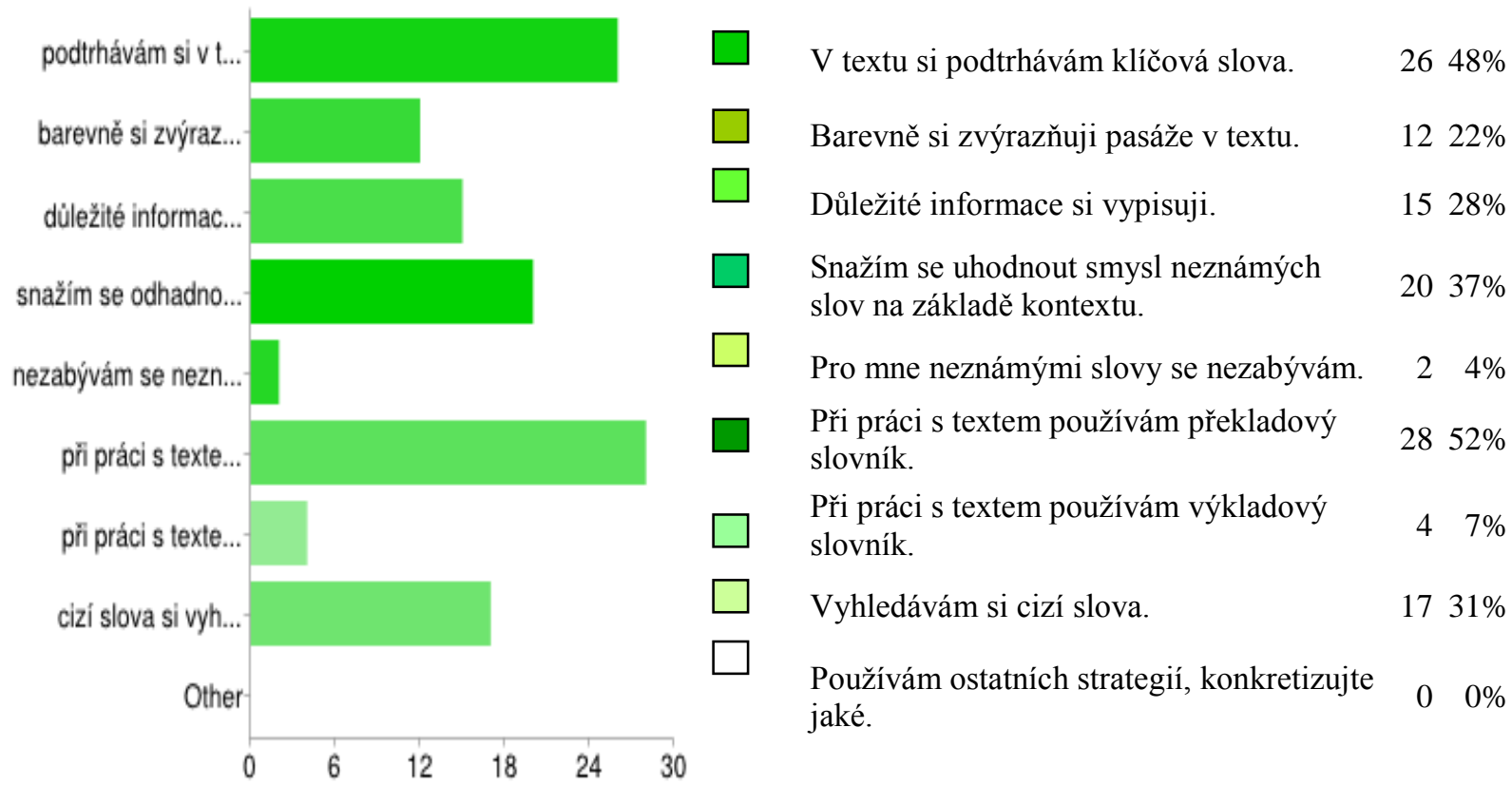

Někteří studenti volili více než jednu možnost, proto procentuální údaje převyšují v součtu hladinu $100 \%$.

Zdroj: Vlastni

Fig. 1: Ukázka vyhodnocení jedné z položek ze sebeevaluačního dotazníku

Druhou část našeho výzkumu pak představoval vlastní výzkum dovednosti práce studujících s odborným textem. Na tomto místě se však nebudeme s ohledem na daný rozsah článku 
zabývat charakteristickými rysy odborného textu, kterými se odlišuje od textů obecného charakteru. Domníváme se totiž, že typické rysy odborného textu jsou čtenářům dostatečně známy (popř. srov. např. [16] nebo [17]).

Pro zkoumání vlastní dovednosti práce s odborným textem jsme použili tři různé odborné texty s obsahovým zaměřením na studium v zahraničí s odpovídajícím lexikálním i gramatickým materiálem odpovídajícím oběma úrovním (B1 a B2). Důvodem pro tuto volbu byl široký rozptyl odborného zaměření studia zúčastněných studujících, námi zvolený druh odborného textu jsme tak považovali za tematicky společný pro všechny respondenty.

Cílem našeho výzkumu byl, po vyhodnocení výsledků našeho pilotního výzkumu, kromě shora uvedeného, i pokus o (re)definici již stávajících deskriptorů SERR nebo o formulaci nových deskriptorů s ohledem na kompetence potřebné pro práci s odborným jazykem nejen pro potřeby studujících, nýbrž i pro profesní účely odborníků pohybujících se v akademickém nebo odborně zaměřeném pracovním prostředí, tedy např. pro jejich vlastní praxi, kariéru, mobilitu, konkurenceschopnost apod.

Praktická část výzkumu práce s textem obsahovala různé modality cvičení zahrnující v sobě cvičení předtextová, textová i potextová. V úvodu jsme použili tzv. předtextové cvičení (typ čtení: orientační), kdy jsme studentům předložili text, přičemž jejich úkolem bylo přečíst si pouze nadpis, krátký perex k textu (2 věty) a zaměřit se na layout textu (text obsahoval grafy a tabulky). Na základě těchto informací měli studující za úkol prezentovat svá vlastní očekávání k předloženému textu. S využitím procesů uplatňujících se při percepci a dekódování textu (výše uvedené bottom-up a top-down procesy) byli studující s to formulovat svá očekávání, která se v $53 \%$ kryla s obsahem textu. Z hlediska psycholingvistiky se jedná u studujících o schopnost prediktability.

Z textových cvičení jsme zvolili tři typy, a to konkrétně tzv. multiple-choice-cvičení ( $82 \%$ úspěšnost), cvičení rekonstrukční (rekonstrukce zpřeházených odstavců s následným doplněním samostatně formulovaných nadpisů k odstavcům, 76\% úspěšnost), jakož i cvičení s cílenými otázkami zaměřenými na porozumění textu ( $68 \%$ úspěšnost). Navíc jsme zařadili i cvičení gramatická a lexikální, nebot' jsme chtěli ověřit, do jaké míry respondenti ovládají potřebné jazykové prostředky. Jednalo se o gramatická cvičení transformační (náhrada aktiva pasívem, přímé řeči nepřímou, verbalizace verbonominálních vazeb, verbalizace nominálních struktur, 57\% úspěšnost). Jako problematická se ukázala být délka a hloubka vět, která byla v některých pasážích navíc komplikována pro německý odborný jazyk typickými rozvitými atributivními vazbami. V oblasti lexikologie jsme se zaměřili na dekódování kompozit a derivátů, stejně tak jako na dekódování zkratek (74\% úspěšnost).

Z potextových cvičení jsme pak nakonec vybrali cvičení, v němž měli respondenti za úkol interpretovat vlastními slovy přečtený text (tentokrát již bez opory o text) a vyjádřit k němu své stanovisko. Přri vyhodnocování této úlohy jsme se zaměřili na míru vystižení hlavní myšlenky (myšlenek) obsažených v původním textu a na formulaci vlastního postoje $\mathrm{k}$ diskutabilním bodům textu. Míra úspěšnosti byla u našich respondentů $63 \%$.

Na základě získaných dat jsme se následně pokusili o již zmíněnou (re)definici, (re)formulaci deskriptorů pro dovednost práce s odborně zaměřeným textem, které připojujeme výběrově níže v tabulkách č. 1,2 a 3 . S ohledem na stanovený rozsah uvádíme deskriptory toliko pro úroveň B2 a ze stejného důvodu vynecháváme deskriptory popisující jazykové prostředky. 
Tab. 1: Ukázka deskriptorů pro úroveň B2: „Co studující dokáže“

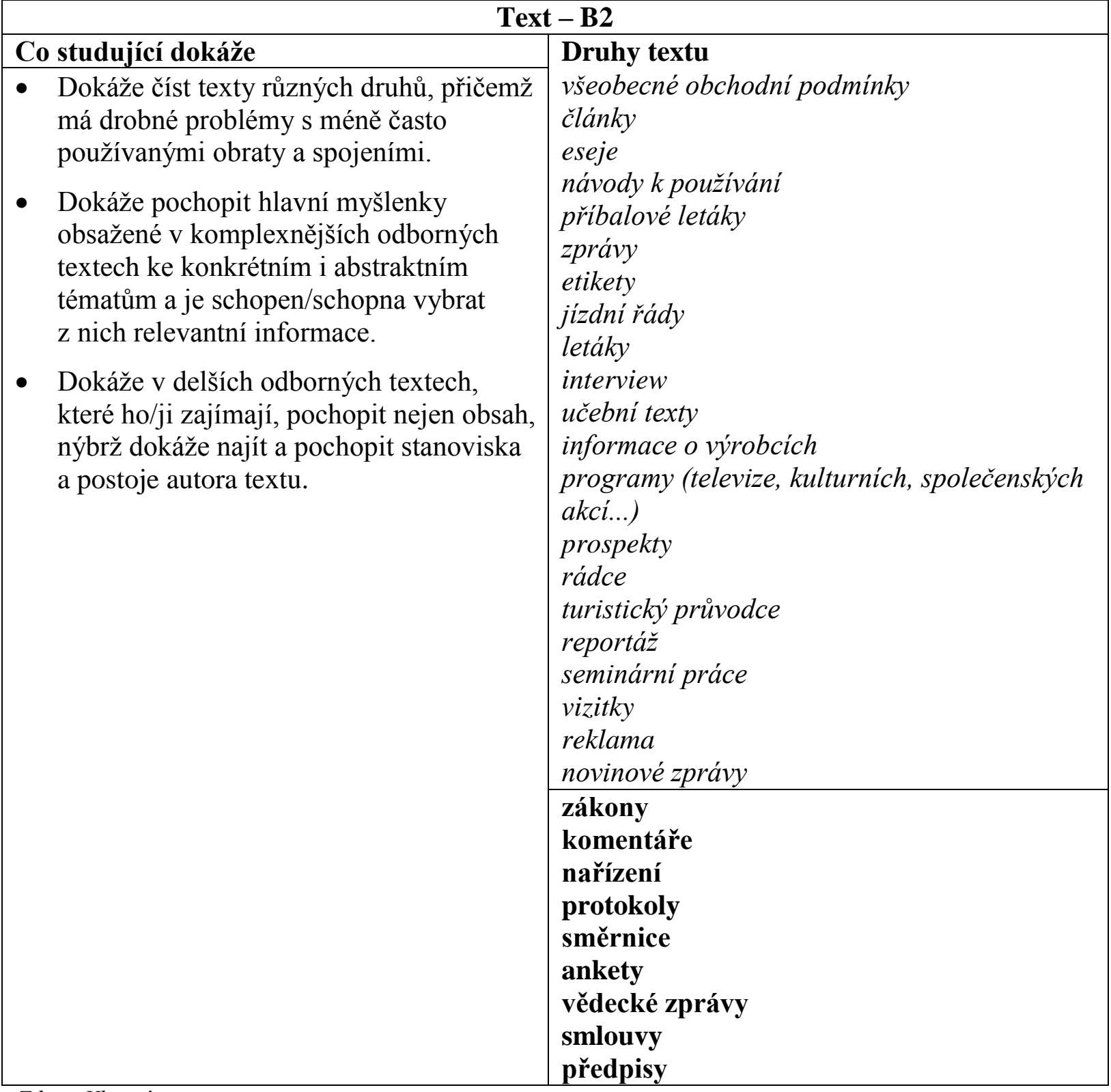

Zdroj: Vlastní 
Tab. 2: Ukázka deskriptorů pro úroveň B2: „Strategie“

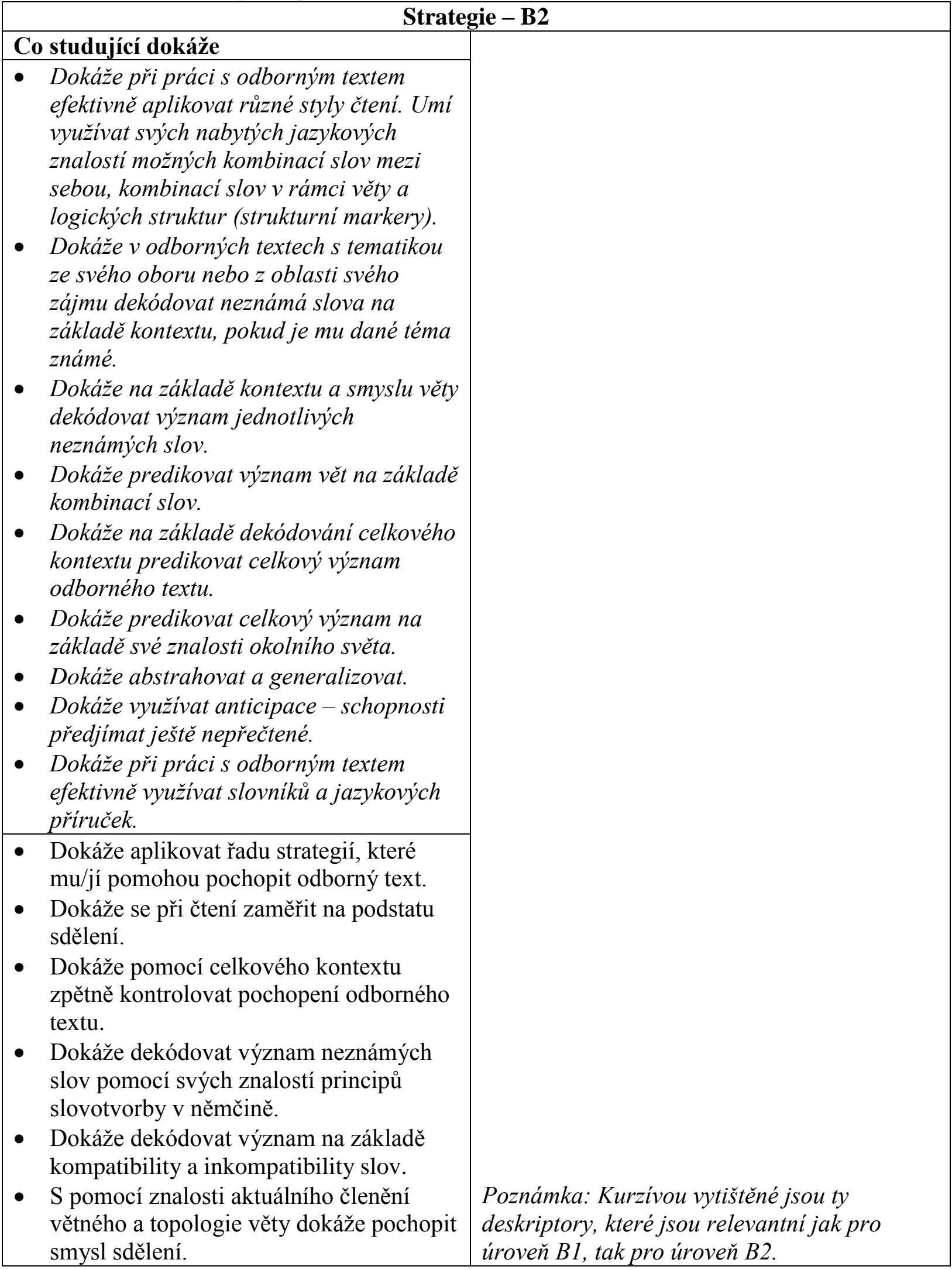

Zdroj: Vlastni 
Tab. 3: Ukázka deskriptorů pro úroveň B2: Sebehodnocení uživatele jazyka- „Co umím“

\begin{tabular}{|l|}
\hline \multicolumn{1}{|c|}{ Dovednost čtení - „Co umím“ - B2 } \\
\hline $\begin{array}{l}\text { Studící umí vybrat z odborného textu relevantní informace týkající se stipendijního programu, } \\
\text { aby byl na jejich základě schopen posoudit, jaké využití a konsekvence pro něho text má. }\end{array}$ \\
\hline $\begin{array}{l}\text { Studující se umí rychle zorientovat v textu, pochopit bez výraznějších obtíží jeho obsah } \\
\text { a v následně se rozhodnout, zda se je pro něho žádoucí detailněǰ̌i čtení či nikoli. }\end{array}$ \\
\hline Studující umí v odborně zaměřených textech globálně pochopit hlavní stanoviska autorů. \\
\hline $\begin{array}{l}\text { Studující umí do detailu porozumět textu, který tematicky přímo souvisí s předmětem } \\
\text { jeho/jejího studia. }\end{array}$ \\
\hline $\begin{array}{l}\text { Studující umí pochopit texty, které tematicky přesahují rámec jeho/jejího oboru, může-li si } \\
\text { vyhledat ve slovníku jemu/jí neznámé výrazy. }\end{array}$ \\
\hline $\begin{array}{l}\text { Studující umí porozumět korespondenci, která souvisí s jeho/jejím oborem, nebo má vztah } \\
\text { k jeho/jejímu studiu. }\end{array}$ \\
\hline $\begin{array}{l}\text { Studující umí pracovat s příručkami a návody k použití a umí v nich vyhledat potřebné } \\
\text { relevantní informace. }\end{array}$ \\
\hline $\begin{array}{l}\text { Studující umí porozumět interpretovanému odbornému textu, např. předčítanému manuálu, } \\
\text { a umí pochopit hlavní body. }\end{array}$ \\
\hline $\begin{array}{l}\text { Studující je s to pochopit kritické texty týkající se aktuálních událostí a umí shrnout hlavní } \\
\text { myšlenky. }\end{array}$
\end{tabular}

Zdroj: Vlastní

\section{Závěr}

V našem př́spěvku jsme ve zkratce nastínili procesy zpracování psaného textu, jakož i strategie, které čtenáři, $\mathrm{v}$ našem případě studujícím nefilologicky zaměřených studijních oborů disponující kompetencí B1 a B2 dle SERR, aplikují při práci s textem za účelem jeho dekódování a pochopení.

Článek zároveň prezentuje výsledky pilotního výzkumu k danému tématu, jehož účastníky byli shora uvedení studenti Metropolitní univerzity Praha. V našem případě se jednalo o kombinovaný kvalitativně-kvantitativní výzkum, $\mathrm{v}$ jehož rámci jsme aplikovali dvě výzkumné metody, explorativní metodu dotazníku a metodu didaktického testu. Cílem našeho pilotního výzkumu bylo zaprvé zjistit, kterých čtenářských strategií studující využívají, zadruhé, do jaké míry jsou respondenti schopni porozumět odbornému textu. Následně provedená analýza výsledků ukázala, že studující aplikují při práci s neznámým textem většinu z v odborné literatuře popisovaných strategií, druhá část pak potvrdila, že jsou stavu pracovat $\mathrm{s}$ neznámým odborným textem takovým způsobem, aby došlo nejen $\mathrm{k}$ jeho úspěšnému dekódování, ale i pochopení v něm obsažených implicitních významů.

Dalším krokem byl náš pokus o reformulace stávajících deskriptorů SERR, resp. pokus o nové formulace, které budou odpovídat potřebám odborného jazyka $\mathrm{v}$ akademickém a profesním prostředí. Domníváme se, že by mohly tyto deskriptory pro odborný jazyk posloužit jako nadstavba pro deskriptory dnes používaného Rámce. To platí zejména pro sebehodnocení uživatele jazyka a pro specifické druhy textu.

Význam reformulací deskriptorů pro práci s odborným textem spatřujeme $\mathrm{v}$ tom, že se jimi mohou řídit nejen studující či odborníci pracující s odborným jazykem při posuzovaní svých vlastních cizojazyčných kompetencí, nýbrž že je mohou využívat také učitelé německého 
jazyka jak pro svou výuku studentů odborně zaměřených studijních oborů, tak i při tvoření učebních materiálů. Naše výsledky a závěry by zároveň mohly posloužit k zamyšlení se nad komplexnějším rozšířením stávajícího SERR i pro odborný jazyk.

\section{Literatura}

[1] SCHRÖDER, H.: Aspekte einer Didaktik / Methodik des fachbezogenen Fremdsprachenunterrichts (DaF). Frankfurt am Main Verlag: Peter Lang, 1988, str. 3. ISBN 978-3820416633

[2] VESELÝ, O.: Leseverstehen im fachbezogenen Deutschunterricht für Tschechen. Ústí nad Labem: Albis international, 1996. ISBN 80-901761-7-8.

[3] WEIS, U.: Lesen in der Fremdsprache Deutsch. Norderstedt: Books on Demand, 2000. ISBN 978-3898114370.

[4] JUNG, H-S.: Das Lesen fachsprachlicher Texte im Deutsch als FremdspracheUnterricht. In: Altmayer, C.; Forster, R.; Grub, F. T. (editors): Deutsch als Fremdsprache in Wissenschaft und Unterricht. Frankfurt am Main; Wien, 2004, str. 105n. ISBN 3-631-52008-5.

[5] PRŮCHA, J.; WALTEROVÁ, E.; MAREŠ, J.: Pedagogický slovník. 4. vydání. Praha: Portál, 2003, s. 35. ISBN 80-7178-772-8.

[6] BESEDOVÁ, P.: Literatura pro děti a mládež ve výuce cizích jazyků. Hradec Králové: Gaudeamus, 2014, str. 36. ISBN 978-80-7435-393-2.

[7] VYGOTSKIJ, L. S.: Psychologie myšlení a řeči. Praha: Portál, 2004. ISBN 80-7178943-7.

[8] LACHOUT, M.: Kde bydli řeč. Jazyk a myšlení - osvojování, modely a praxe. Praha: Metropolitan University Prague Press, 2012, str. 82, 71. ISBN 978-80-86855-89-9.

[9] LUTJEHARMS, M.: Lesen im Fremdsprachenunterricht. In: Jung, U. O. H. (Hrsg.): Praktische Handreichung für Fremdsprachenlehrer. Frankfurt am Main: Lang, 1998, str. 281-287. ISBN 978-3631542514.

[10] WOLFF, D.: Strategien des Textverstehens. Was wissen Fremdsprachenlerner über den eigenen Verstehensprozess? In: Rampillon, U.; Zimmermann, G. (editors): Strategien und Techniken beim Erwerb fremder Sprachen. Ismaning: Hueber Verlag, 1997. ISBN 3-19-006624-8.

[11] WOLFF, D.: Lern- und Arbeitstechniken für den Fremdsprachenunterricht: Versuch einer theoretischen Fundierung. In: Multhaupt, U; Wolff, D. (editors): Prozessorientierung im Fremdsprachenunterricht. Frankfurt a.M.: Diesterweg, 1992, str. 101-120. ISBN 3-425-04455-9.

[12] BIMMEL, P.; RAMPILLON, U.: Lernerautonomie und Lernstrategien. München: Langenscheidt, 2000, str. 96, 65. ISBN 978-3468496516.

[13] BOHUŠOVÁ, Z.: Primárnost' ústnej odbornej cudzojazyčnej komunikácie. In: Nová filologická revue: časopis o súčasnej lingvistike, literárnej vede, translatológii a kulturológii. Roč. 4, č. 1. Banská Bystrica: Univerzita Mateja Bela, Fakulta humanitných vied, 2012. str. 6-20. ISSN 1338-0583.

[14] BOHUŠOVÁ, Z.: Zwischen Mündlichkeit und Schriftlichkeit - SOWOHLALSAUCH und WEDERNOCH. In: Kusová, J.; Malechová, M.; Vodrážková, L. (editors): Deutsch ohne Grenzen. Linguistik. Brno: Tribun EU, 2015, str. 365-379. ISBN 978-80-2630939-0. 
[15] BIMMEL, P.: Wegweiser im Dschungel der Texte. Fremdsprache Deutsch 2, 1990, str. 10-15. ISBN 978-3503166497.

[16] HENDRICH, J. et al.: Didaktika cizich jazyki̊. Praha: SPN, 1989, str. 119.

[17] ROELCKE, T.: Fachsprachen. 3. vydání. Berlin Erich Schmidt Verlag, 2010. ISBN 978-3-503-12221-9. 


\section{Perception Skills AND Written-TeXt Decoding Among Students From NON-PHILOLOGICAL SUBJECTS}

This paper examines reading and comprehension skills. Following a theoretical introduction, the paper describes a pilot study among selected Czech university students from nonphilological subjects. The study's aim was to ascertain how the respondents work with academic texts, what strategies they use, and how well they manage to successfully decode such texts. The paper proposes a revision of key CEFR skills to accommodate reading and comprehension of academic texts.

\section{DiE FERTIGKEIT DER PERZEPTION UND DER DEKODIERUNG EINES GESCHRIEBEN TEXTES (NICHT NUR) BEI STUDIERENDEN NICHTPHILOLOGISCHER STUDIENFÄCHER}

Dieser Beitrag präsentiert zuerst sowohl diejenigen Verarbeitungsprozesse, die beim Leseverstehen eine gravierende Rolle spielen, als auch solche Strategien, die für das Dekodieren und Verstehen eines (Fach-) Textes von Bedeutung sind. Weiterhin stellt der Beitrag Ergebnisse einer Pilotforschung zur Problematik der Arbeit mit fachorientierten Texten vor, die der Autor an der Metropolitan Universität Prag durchgeführt hat. Auf Grund der festgestellten Daten entstand ein Entwurf der Schlüsselkompetenzen nach dem GeRS mit Hinsicht auf die Fertigkeit „Leseverstehen“ fachorientierter Texte.

\section{UMIEJĘTNOŚĆ PERCEPCJI I DEKODOWANIA TEKSTU PISANEGO (NIE TYLKO) WŚRÓD STUDENTÓW KIERUNKÓW NIEFILOLOGICZNYCH}

Artykuł poświęcony jest receptywnej umiejętności czytania ze zrozumieniem. Po teoretycznym wprowadzeniu autor przedstawia badania pilotażowe, jakie zrealizowano wśród wybranych czeskich studentów kierunków niefilologicznych. Celem badań było ustalenie sposobu, w jaki respondenci pracują ze specjalistycznym tekstem, jakie stosują strategie i czy są W stanie pomyślnie taki tekst dekodować. W oparciu o pozyskane dane opracowano propozycję kompetencji kluczowych wg ERRJ przeformułowanych pod kątem czytania specjalistycznego tekstu ze zrozumieniem. 